\title{
Neutron Radiation Tests about FeCr Slag and Natural Zeolite Loaded Brick Samples
}

\author{
Vedat Veli Cay, ${ }^{1}$ Mucahit Sutcu, ${ }^{2}$ Osman Gencel, ${ }^{3}$ and Turgay Korkut ${ }^{4}$ \\ ${ }^{1}$ School of Aviation, Dicle University, 21280 Diyarbakir, Turkey \\ ${ }^{2}$ Department of Materials Science and Engineering, Izmir Katip Celebi University, 35620 Izmir, Turkey \\ ${ }^{3}$ Department of Civil Engineering, Faculty of Engineering, Bartin University, 74100 Bartin, Turkey \\ ${ }^{4}$ Department of Nuclear Energy Engineering, Faculty of Engineering, Sinop University, Sinop, Turkey
}

Correspondence should be addressed to Osman Gencel; osmangencel@gmail.com

Received 20 November 2013; Accepted 2 March 2014; Published 10 April 2014

Academic Editor: Jakrapong Kaewkhao

Copyright (c) 2014 Vedat Veli Cay et al. This is an open access article distributed under the Creative Commons Attribution License, which permits unrestricted use, distribution, and reproduction in any medium, provided the original work is properly cited.

\begin{abstract}
Neutron shielding performances of new brick samples are investigated. Brick samples including 10, 20, and 30 percentages of ferrochromium slag (FeCr waste) and natural zeolite are prepared and mechanical properties are obtained. Total macroscopic cross sections are calculated by using results of $4.5 \mathrm{MeV}$ neutron transmission experiments. As a result, neutron shielding capacity of brick samples increases with increasing FeCr slag and natural zeolite percentages. This information could be useful in the area of neutron shielding.
\end{abstract}

\section{Introduction}

Bricks, made of different materials, are the most widely basic structures used in the world. The use of the brick dates back to $7500 \mathrm{BC}$. It has low cost. Also it is useful and widely produced as building material. There are too many studies about brick as construction and building material because of its widespread use. Also radiation shielding properties of bricks have been investigated in several papers. A radiation protection study was made about medical X-ray device. In this paper absorbed doses were obtained. Researchers have used tungsten-rubber sheets, lead, plasterboard, and bricks in shielding design [1]. In another study, a brick castle design was used to calibrate gamma radiation source [2]. Anthropogenic doses were studied on examples of some of the brick buildings suffered from radioactive contamination at 19491956 in Russia [3]. Responses of brick samples to gamma irradiation were investigated by Awadallah and Imran. As a result of this study, it is found that gamma ray attenuation coefficient of brick is higher than concrete [4]. Natural radioactivity levels of brick used for the construction of the dwelling in Iran area were determined [5]. Other materials like water-extended polyester, to shield neutrons, have been studied [6], as well as concrete bricks with aggregates [7].

Despite these studies, studies about neutron shielding properties of brick are limited. Kharitonov developed a new technology for brick production and performed thermal neutron shielding experiments on produced sample. According to the results of this study, thermal neutron absorption capacity of brick is greater (about 75\%) than graphite [8]. In other studies neutron radiography and neutron scattering techniques on brick samples were evaluated [9-12].

The number of applications including different radiation types increased rapidly in recent years. Therefore, radiation protection has become an important issue. There are several studies about usage of waste materials to design novel radiation protection materials [13-16].

Currently, since metallic ferrochrome production has increased, large quantities of their waste as ferrochromium slag occur at the result of the metallurgical processing. So, the recycling of wastes as ferrochrome slag is not only economically viable but also it is considered as an environmental friendly approach in the production of fired clay bricks. These bricks are low-cost building materials. These wastes may be 
TABLE 1: Chemical composition of the raw materials used.

\begin{tabular}{lccc}
\hline $\begin{array}{l}\text { Compositions } \\
\text { (wt.\%) }\end{array}$ & Brick clay & $\begin{array}{c}\text { Ferrochromium } \\
\text { slag }\end{array}$ & Natural zeolite \\
\hline $\mathrm{Al}_{2} \mathrm{O}_{3}$ & 15.7 & 23.47 & 11.82 \\
$\mathrm{SiO}_{2}$ & 61.6 & 29.38 & 67.1 \\
$\mathrm{Fe}_{2} \mathrm{O}_{3}$ & 6.8 & 1.55 & 1.47 \\
$\mathrm{MgO}$ & 2.3 & 38.5 & 1.15 \\
$\mathrm{CaO}$ & 2.16 & 0.93 & 2.16 \\
$\mathrm{~K}_{2} \mathrm{O}$ & 2.36 & 0.06 & 3.43 \\
$\mathrm{Na}_{2} \mathrm{O}$ & 0.82 & 0.15 & 0.37 \\
$\mathrm{Cr}_{2} \mathrm{O}_{3}$ & - & 5.17 & - \\
$\mathrm{LOI}^{1}$ & 7.25 & 1.5 & 12.5 \\
\hline
\end{tabular}

${ }^{1}$ Loss on ignition.

alternatively used in the brick body in order to produce a radiation protection material $[8,16,17]$. Mineralogical and compositional content of ferrochromium slag and zeolite is well matched with that of brick structure.

In present paper, FeCr slag and natural zeolite are added in brick commonly used in the construction of the buildings and neutron transmission experiments are performed. Seven different brick samples including different $\mathrm{FeCr}$ slag and natural zeolite percentages are irradiated $4.5 \mathrm{MeV}$ neutron particles from ${ }^{241} \mathrm{Am} / \mathrm{Be}$ fast neutron source. This study is important in terms of waste management and nuclear safety engineering areas.

\section{Experimental Procedure}

2.1. Materials and Method. In this study, production of radiation resistant bricks was accomplished from mixtures of brick clay and additives containing ferrochromium ( $\mathrm{FeCr}$ ) slag and natural zeolite. The physical and chemical properties of the raw materials were previously characterized. Chemical composition of the raw materials used is presented in Table 1. The raw materials were initially subjected to pr-treatments such as drying and ball milling. The raw materials subjected to ball milling sieved under 100 micron particle size. Chemical analysis of brick clay, FeCr slag, and zeolite was made by using X-ray fluorescence (XRF) spectrometer. Then, they were characterized by X-ray diffractometer (XRD) for their mineral content.

In this study, brick clay obtained from a brick manufacturer (Üç Yıldız Tuğla) in Bartın, Turkey, was used. Chemical analysis of the brick clay is presented in Table 1 in oxide form. According to the analysis, the clay includes a large fraction of $\mathrm{SiO}_{2}$ in addition to $\mathrm{Al}_{2} \mathrm{O}_{3}, \mathrm{Fe}_{2} \mathrm{O}_{3}$, $\mathrm{CaO}, \mathrm{MgO}$, and $\mathrm{K}_{2} \mathrm{O}$. Loss on ignition of brick raw material upon heating at $1000^{\circ} \mathrm{C}$ was measured as $7.25 \%$. According to the XRD analysis, the clay includes mainly quartz, illite/muscovite $\left(\mathrm{KAl}_{2}\left(\mathrm{AlSi}_{3} \mathrm{O}_{10}\right)(\mathrm{OH})_{2}\right)$, and clinochlore $\left((\mathrm{Mg}, \mathrm{Al}, \mathrm{Fe})_{6}(\mathrm{Si}, \mathrm{Al})_{4} \mathrm{O}_{10}(\mathrm{OH})_{8}\right)$ constituents.

The ferrochromium slag is a waste material obtained from the manufacture of ferrochromium metal in the Eti Krom Works, Elazığ, Turkey. The specific gravity of slag is
TABLE 2: Prepared mixtures from the raw materials used (wt.\%).

\begin{tabular}{lcccc}
\hline Mix code & $\begin{array}{c}\text { Brick } \\
\text { clay }\end{array}$ & $\begin{array}{c}\text { Ferrochromium } \\
\text { slag }\end{array}$ & $\begin{array}{c}\text { Natural } \\
\text { zeolite }\end{array}$ & $\begin{array}{c}\text { Thickness } \\
(\mathrm{cm})\end{array}$ \\
\hline 0 & 100 & 0 & 0 & 1.61 \\
$10 \mathrm{~F}$ & 90 & 10 & 0 & 1.94 \\
$20 \mathrm{~F}$ & 80 & 20 & 0 & 1.88 \\
$30 \mathrm{~F}$ & 70 & 30 & 0 & 1.90 \\
$10 \mathrm{Z}$ & 90 & 0 & 10 & 1.77 \\
$20 \mathrm{Z}$ & 80 & 0 & 20 & 1.87 \\
$30 \mathrm{Z}$ & 70 & 0 & 30 & 2.03 \\
\hline
\end{tabular}

$3.17 \mathrm{~g} / \mathrm{cm}^{3}$. The chemical composition of the slag used is presented in Table 1 . The slag consists mainly of $\mathrm{SiO}_{2}, \mathrm{Al}_{2} \mathrm{O}_{3}$, and $\mathrm{MgO}$ in different phases such as spinel $\left(\mathrm{MgO} \cdot \mathrm{Al}_{2} \mathrm{O}_{3}\right)$ and forsterite $\left(\mathrm{MgO} \cdot \mathrm{SiO}_{2}\right)$ as well as chromium and iron oxides and fewer amounts of other metal oxides [16]. Another raw material is natural zeolite obtained from Rota Madencilik, Gördes, Turkey. The specific gravity of zeolite is $1.85 \mathrm{~g} / \mathrm{cm}^{3}$. The chemical composition of the zeolite used is presented in Table 1. Natural zeolites have voids and three-dimensional systems of pore channels which are typically in the range of molecular dimensions. Zeolites are crystalline aluminosilicates containing elements such as sodium, potassium, magnesium, and calcium. X-ray analysis of the zeolite showed the characteristic peaks of clinoptilolite as well as presence of quartz, cristobalite, and K-feldspar.

2.2. Brick Production Procedure. Initially, the raw materials were dried at $100^{\circ} \mathrm{C}$ in a dry oven. Then, they were powdered by a ball mill. The mixtures containing brick clay with ferrochromium slag and natural zeolite addition prepared in a mixer. Brick clay was dispersed into water and was mixed with the selected additive (Table 2). Rectangular samples were formed by a slurry casting process. Prepared slurry mixtures were cast into the molds placed onto plaster blocks in order to suck excess water. In the meantime, top surface of the slurry was compressed by hand in order to ensure complete filling of the mold. Green samples were removed from the mold after $2 \mathrm{~h}$ and left to dry in ambient conditions for $24 \mathrm{~h}$. Samples were further dried in an oven maintained at $50^{\circ} \mathrm{C}$ for $12 \mathrm{~h}$ and then at $100^{\circ} \mathrm{C}$ for $24 \mathrm{~h}$. The dry samples were fired in a laboratory-type electrical furnace at the rate of $5^{\circ} \mathrm{C} / \mathrm{min}$ until $900^{\circ} \mathrm{C}$, for 2 hours.

Weight loss and dimensional changes of the samples were measured after drying and firing steps. Bulk density, apparent porosity and water absorption values of the fired samples were measured by Archimedes method. Their mechanical properties like compressive and bending strengths and also their microstructural analysis were performed.

The brick samples showed the dimensional stability during firing at $900^{\circ} \mathrm{C}$ and their linear shrinkages were almost zero. Table 3 shows the experimental results obtained from the brick samples fired at $900^{\circ} \mathrm{C}$. One of produced brick sample is shown in Figure 1. 
TABLE 3: Experimental results of the brick samples fired at $900^{\circ} \mathrm{C}$.

\begin{tabular}{|c|c|c|c|c|c|c|}
\hline $\begin{array}{l}\text { Mix } \\
\text { code }\end{array}$ & Weight loss (\%) & Bulk density $\left(\mathrm{g} / \mathrm{cm}^{3}\right)$ & Porosity (\%) & Water absorption (\%) & Bending strength (MPa) & Compressive strength ( $\mathrm{MPa})$ \\
\hline 0 & 6.76 & 1.68 & 33.9 & 16.5 & 14.1 & 34.9 \\
\hline $10 \mathrm{~F}$ & 5.88 & 1.83 & 34.6 & 16.1 & 13.5 & 32.0 \\
\hline $20 \mathrm{~F}$ & 5.07 & 1.86 & 38.2 & 18.1 & 7.1 & 29.8 \\
\hline $30 \mathrm{~F}$ & 4.69 & 1.90 & 38.6 & 17.4 & 9.2 & 27.5 \\
\hline $10 \mathrm{Z}$ & 7.54 & 1.65 & 37.4 & 20.3 & 8.2 & 22.3 \\
\hline $20 \mathrm{Z}$ & 8.17 & 1.56 & 39.3 & 22.4 & 6.5 & 19.4 \\
\hline $30 Z$ & 8.36 & 1.48 & 42.8 & 25.9 & 6.1 & 14.3 \\
\hline
\end{tabular}

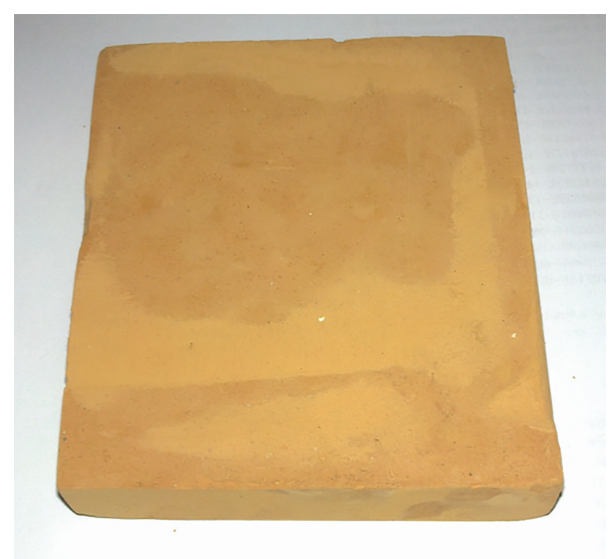

Figure 1: Produced brick sample.

2.3. Neutron Dose Transmission Experiments. The alphaberyllium isotopic neutron sources, like ${ }^{241} \mathrm{Am} / \mathrm{Be}$ and ${ }^{239} \mathrm{Pu} / \mathrm{Be}$, and the spontaneous fission source like ${ }^{252} \mathrm{Cf}$ are widely used [18]. We used a ${ }^{241} \mathrm{Am} / \mathrm{Be}$ alpha-beryllium neutron source to obtain primary neutron beam. Emitted radiations from this neutron source are shown in Table 4. In order to prevent the scattered neutrons, the source was placed in a box consisting of paraffin (against neutrons) and lead (against $59.54 \mathrm{keV}{ }^{241} \mathrm{Am}$ photons). As neutron detector, Canberra NP100B proportional neutron counter was used. Firstly, we measured without the sample between the source and detector. In this way background value $\left(D_{0}\right)$ was obtained. And then to determine $D$ values for each sample, we measured with samples between the source and detector. To achieve $4.5 \mathrm{MeV}$ neutron dose transmissions $(T)$, $D$ values were divided by the value of $D_{0}$ (see (1)):

$$
T=\frac{D}{D_{0}}
$$

After dose transmission values were obtained, we applied (2) to calculate neutron total macroscopic cross sections, $\Sigma$ for each samples [17-21]:

$$
\Sigma=\frac{(\ln (1 / T))}{x} .
$$

In (2), $x$ is thickness of sample. $\Sigma$ value is an important parameter for neutron shielding issue. That is, macroscopic
TABLE 4: Radiation characteristics of ${ }^{241} \mathrm{Am}-\mathrm{Be}$ neutron source ${ }^{1}$.

\begin{tabular}{lccc}
\hline \multicolumn{2}{c}{ Physical half-life: 432.2 years } & \multicolumn{2}{c}{ Specific activity: 127 GBq/g } \\
$\begin{array}{l}\text { Principle } \\
\text { Emissions }\end{array}$ & $E_{\max }(\mathrm{keV})$ & $E_{\text {eff }}(\mathrm{keV})$ & $\begin{array}{c}\text { Dose rate } \\
(\mu \text { Sv/h/GBq at } 1 \mathrm{~m})\end{array}$ \\
\hline Gamma/X-rays & $13.9(42.7 \%)$ & - & - \\
& $59.5(35.9 \%)$ & - & 85 \\
Alpha & 5.443 & & \\
& $(12.8 \%)$ & - & 2 \\
Neutron & 5.486 & & \\
\hline
\end{tabular}

${ }^{1}$ http://stuarthunt.com/pdfs/Americium_241Beryllium.pdf.

cross section value is directly proportional to the neutron shielding capacity of the sample. Experimental design for neutron transmission measurements is demonstrated in Figure 2 .

\section{Results and Discussion}

The obtained results were evaluated for two different additives as natural zeolite and FeCr slag. Macroscopic cross-section value for the bare brick sample (without any additive) is about $0.035 \mathrm{~cm}^{-1}$.

Macroscopic cross section results for natural zeolite additives $(10,20$, and $30 \%)$ in mere brick sample with a polynomial fit can be seen in Figure 3 . As can be seen in this figure, there is a peak value at $20 \%$ additive. In $20 \%$ point $\Sigma$ is 0.09 and it is approximately three times greater than the sample without any additives. A decrease in macroscopic cross section after this value was detected. So, neutron shielding properties of brick can be increased by adding around 20 percent of zeolite.

Obtained $\Sigma$ values for FeCr slag additives (10, 20 and 30\%) with a linear fit were given in Figure 4. As shown in this figure, 4.5 MeV neutron macroscopic cross-section value increase with increasing FeCr slag additive. For example, at 30\% point $\Sigma$ is 0.102 and this value is three times greater than the bare brick sample. Linear fit shows that $\Sigma$ is directly proportional to the adding FeCr slag percentage in bare brick.

The bulk density of brick sample without addition was $1.68 \mathrm{~g} / \mathrm{cm}^{3}$. The sample without addition had a porosity of 


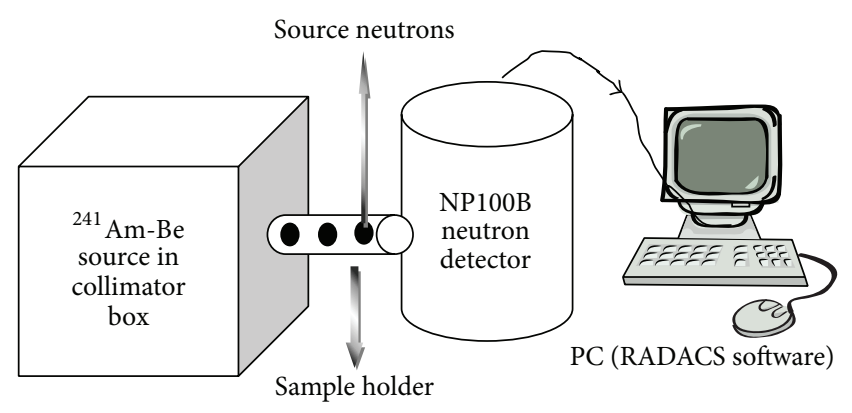

FIgURE 2: Experimental arrangement.

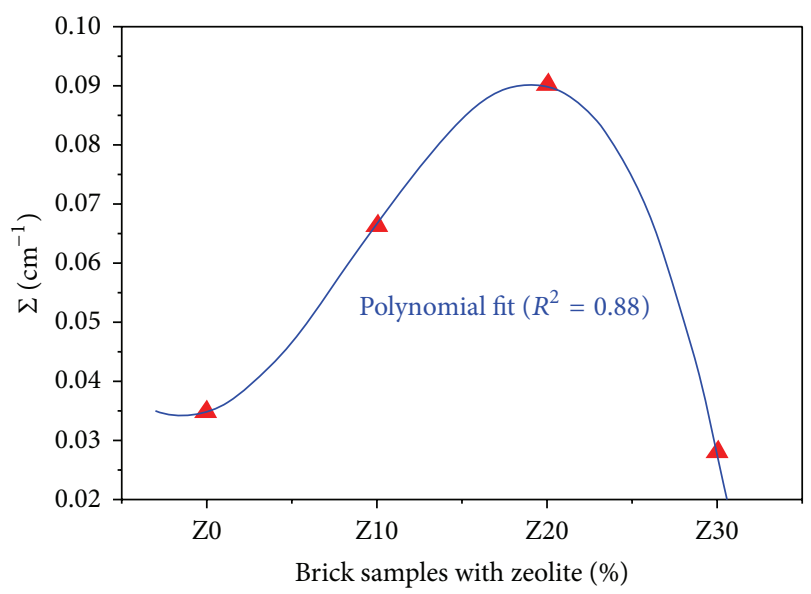

FIgURE 3: $4.5 \mathrm{MeV}$ neutron macroscopic cross sections of bricks as a function of natural zeolite percentage.

$33.9 \%$ and water absorption of $16.5 \%$. The strengths of brick sample without addition were quite well.

The results of brick samples with ferrochromium slag obtained revealed that the bulk densities increased with an increase in the amount of the slag due to its high specific gravity. Bulk density of the bricks with the slag increased from $1.68 \mathrm{~g} / \mathrm{cm}^{3}$ to $1.90 \mathrm{~g} / \mathrm{cm}^{3}$. In these samples, depending on the increase in the ferrochromium slag addition, porosity content and water absorption ratios of the samples increased; accordingly, their compressive strengths decreased.

The results of brick samples with natural zeolite obtained revealed that the bulk densities decreased with increasing of the zeolite content due to its porous structure. Bulk density of the bricks with the natural zeolite decreased from $1.68 \mathrm{~g} / \mathrm{cm}^{3}$ to $1.48 \mathrm{~g} / \mathrm{cm}^{3}$. Depending on the increase in the zeolite addition, porosity and water absorption ratios of the samples increased, while the mechanical strengths were significantly reduced.

The bulk density of brick samples with combined additions showed a close value to that of the brick sample without addition. In these samples, depending on the increase in the ferrochromium slag and natural zeolite addition, porosity and water absorption ratios of the samples showed an increase; accordingly, their compressive strengths decreased. However, compressive and bending strengths of all samples

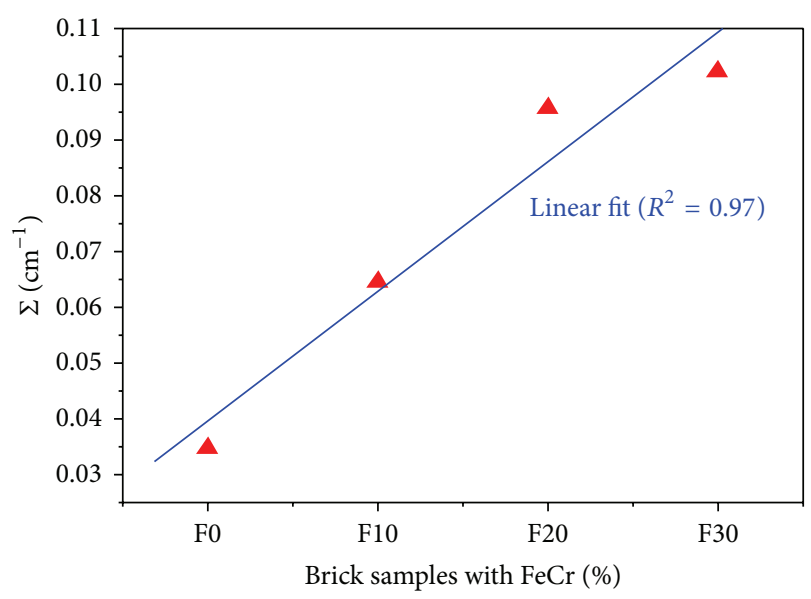

FIgURE 4: 4.5 MeV neutron macroscopic cross sections of bricks as a function of $\mathrm{FeCr}$ slag percentage.

were still higher than the Turkish and corresponding European Standards [19] for strength values.

\section{Conclusions}

We prepared our samples using commercial bricks, FeCr slag, and natural zeolite with different percentages. While bulk density of bricks with FeCr slag increases, bulk density of bricks with zeolite decreases. Both bricks with FeCr slag and natural zeolite have sufficient strengths over $14 \mathrm{MPa}$. All bricks have high porosity that is desired to survive under elevated temperatures. Neutron absorption capability of brick increases with increasing FeCr slag and zeolite additives. The most important result of our study is to recover FeCr wastes in radiation shielding industries. Produced new samples may be used in constructions for protection against neutron radiation.

\section{Conflict of Interests}

The authors declare that there is no conflict of interests regarding the publication of this paper.

\section{References}

[1] D. J. Eaton, R. Gonzalez, S. Duck, and M. Keshtgar, "Radiation protection for an intra-operative X-ray device," British Journal of Radiology, vol. 84, no. 1007, pp. 1034-1039, 2011.

[2] E. R. van der Graaf, J. Limburg, R. L. Koomans, and M. Tijs, "Monte Carlo based calibration of scintillation detectors for laboratory and in situ gamma ray measurements," Journal of Environmental Radioactivity, vol. 102, no. 3, pp. 270-282, 2011.

[3] M. O. Degteva, N. G. Bougrov, M. I. Vorobiova, P. Jacob, and H. Y. Göksu, "Evaluation of anthropogenic dose distribution amongst building walls at the Metlino area of the upper Techa River region," Radiation and Environmental Biophysics, vol. 47, no. 4, pp. 469-479, 2008.

[4] M. I. Awadallah and M. M. A. Imran, "Experimental investigation of $\gamma$-ray attenuation in Jordanian building materials using 
HPGe-spectrometer," Journal of Environmental Radioactivity, vol. 94, no. 3, pp. 129-136, 2007.

[5] A. A. Fathivand, J. Amidi, and A. Najafi, "The natural radioactivity in the bricks used for the construction of the dwelling in Tehran areas of Iran," Radiation Protection Dosimetry, vol. 123, no. 3, pp. 391-393, 2007.

[6] H. R. Vega-Carrillo, E. Manzanares-Acuña, V. M. HernándezDávila, E. Gallego, A. Lorente, and I. Donaire, "Water-extended polyester neutron shield for a ${ }^{252} \mathrm{Cf}$ neutron source," Radiation Protection Dosimetry, vol. 126, no. 1-4, pp. 269-273, 2007.

[7] E. Gallego, A. Lorente, and H. R. Vega-Carrillo, "Testing of a high-density concrete as neutron shielding material," Nuclear Technology, vol. 168, no. 2, pp. 399-400, 2009.

[8] V. I. Kharitonov, "Radiation shielding bricks from metallurgical products," Industrial Ceramics, vol. 22, no. 3, pp. 169-174, 2002.

[9] A. El Abd, A. Czachor, and J. Milczarek, "Neutron radiography determination of water diffusivity in fired clay brick," Applied Radiation and Isotopes, vol. 67, no. 4, pp. 556-559, 2009.

[10] M. N. Islam, M. K. Alam, M. A. Zaman, M. H. Ahsan, and N. I. Molla, "Application of neutron radiography to building industries," Indian Journal of Pure and Applied Physics, vol. 38, no. 5, pp. 348-354, 2000.

[11] G. C. Charalambopoulou, P. Karamertzanis, E. S. Kikkinides, A. K. Stubos, N. K. Kanellopoulos, and A. T. Papaioannou, "A study on structural and diffusion properties of porcine stratum corneum based on very small angle neutron scattering data," Pharmaceutical Research, vol. 17, no. 9, pp. 1085-1091, 2000.

[12] M. Erdem, O. Baykara, M. Doĝru, and F. Kuluöztürk, "A novel shielding material prepared from solid waste containing lead for gamma ray," Radiation Physics and Chemistry, vol. 79, no. 9, pp. 917-922, 2010.

[13] A. El-Sayed Abdo, M. A. M. Ali, and M. R. Ismail, "Natural fibre high-density polyethylene and lead oxide composites for radiation shielding," Radiation Physics and Chemistry, vol. 66, no. 3, pp. 185-195, 2003.

[14] A. Rimpler, M. Börst, and D. Seifarth, "Neutron measurements around a TN85-type storage cask with high-active waste," Radiation Measurements, vol. 45, no. 10, pp. 1290-1292, 2010.

[15] M. Alwaeli and J. Nadziakiewicz, "Recycling of scale and steel chips waste as a partial replacement of sand in concrete," Construction and Building Materials, vol. 28, no. 1, pp. 157-163, 2012.

[16] O. Gencel, F. Koksal, C. Ozel, and W. Brostow, "Combined effects of fly ash and waste ferrochromium on properties of concrete," Construction and Building Materials, vol. 29, pp. 633640, 2012.

[17] T. Korkut, O. Gencel, E. Kam, and W. Brostow, "X-ray, gamma and neutron radiation tests on epoxy-ferrochromium slag composites by experiments and Monte Carlo simulations," International Journal of Polymer Analysis and Characterization, vol. 18, no. 3, pp. 224-231, 2013.

[18] H. R. Vega-Carrillo, M. R. Martinez-Blanco, V. M. HernandezDavila, and J. M. Ortiz-Rodriguez, "Spectra and dose with ANN of ${ }^{252} \mathrm{Cf}$, ${ }^{241} \mathrm{Am}-\mathrm{Be}$, and ${ }^{239} \mathrm{Pu}-\mathrm{Be}$," Journal of Radioanalytical and Nuclear Chemistry, vol. 281, no. 3, pp. 615-618, 2009.

[19] T. Korkut, A. Karabulut, G. Budak, B. Aygün, O. Gencel, and A. Hançerlioĝullari;, "Investigation of neutron shielding properties depending on number of boron atoms for colemanite, ulexite and tincal ores by experiments and FLUKA Monte Carlo simulations," Applied Radiation and Isotopes, vol. 70, no. 1, pp. 341-345, 2012.
[20] T. Korkut, A. Ün, F. Demir et al., "Neutron dose transmission measurements for several new concrete samples including colemanite," Annals of Nuclear Energy, vol. 37, no. 7, pp. 996998, 2010.

[21] T. Korkut, A. Karabulut, G. Budak, and H. Korkut, "Investigation of fast neutron shielding characteristics depending on boron percentages of $\mathrm{MgB}_{2}, \mathrm{NaBH}_{4}$ and $\mathrm{KBH}_{4}$, Journal of Radioanalytical and Nuclear Chemistry, vol. 286, no. 1, pp. 6165, 2010. 


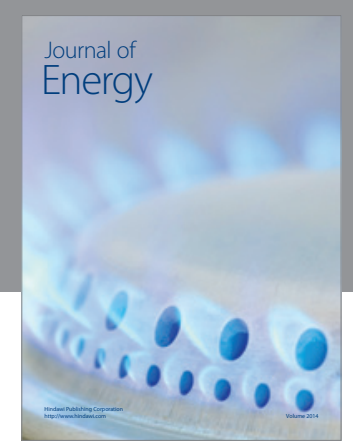

Journal of

Industrial Engineering
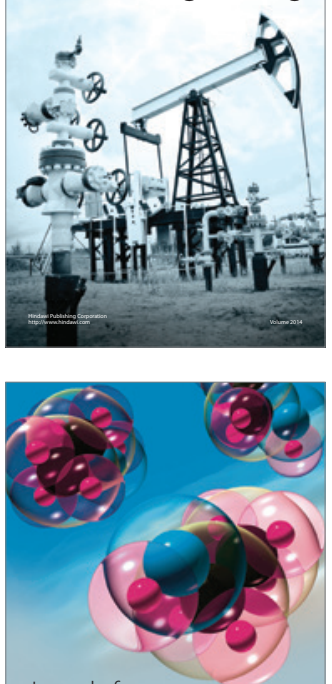

Fuels
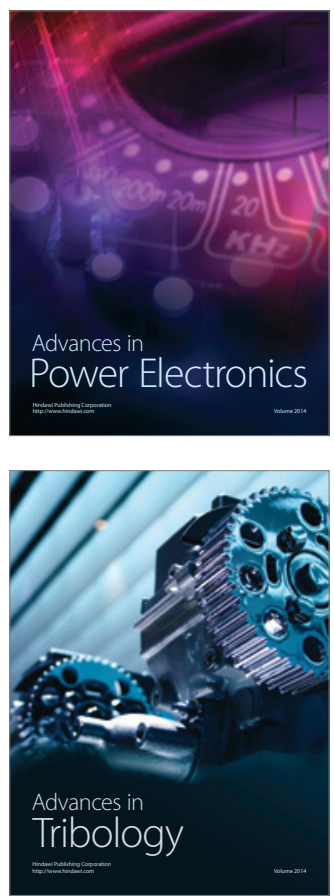

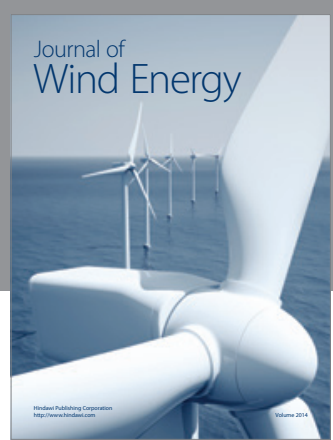

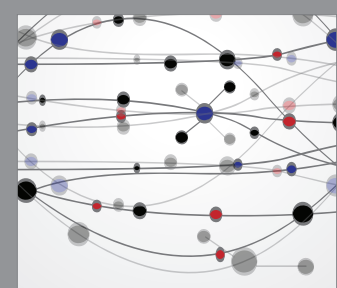

The Scientific World Journal

Submit your manuscripts at http://www.hindawi.com

Journal of

Structures
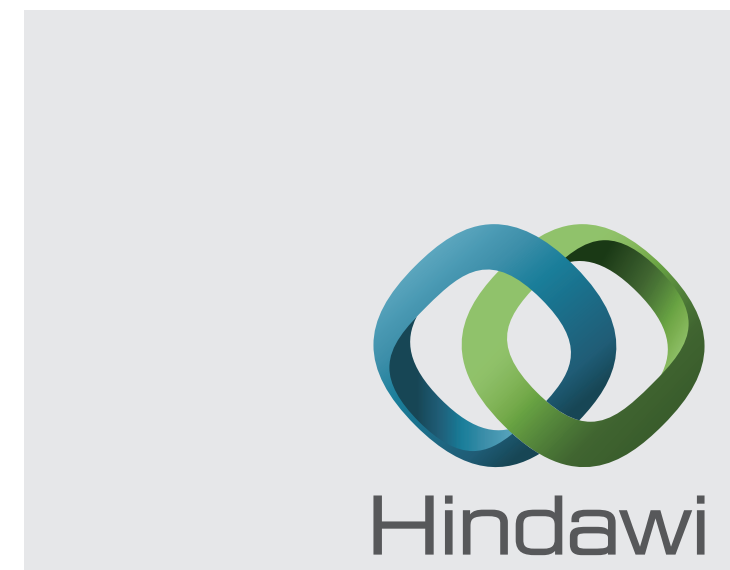

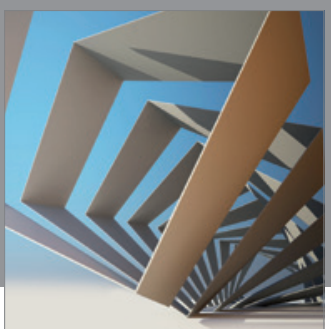

Rotating

Machinery
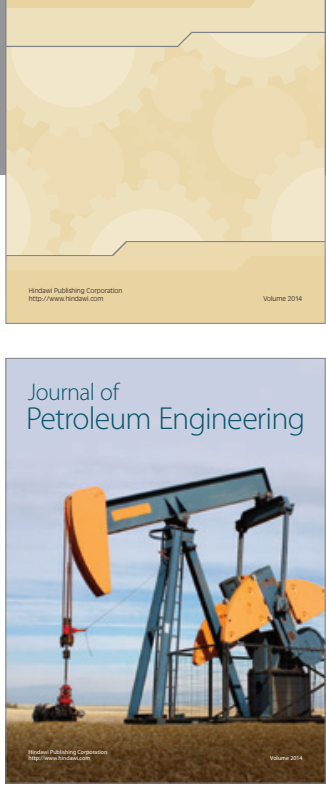

Journal of

Solar Energy
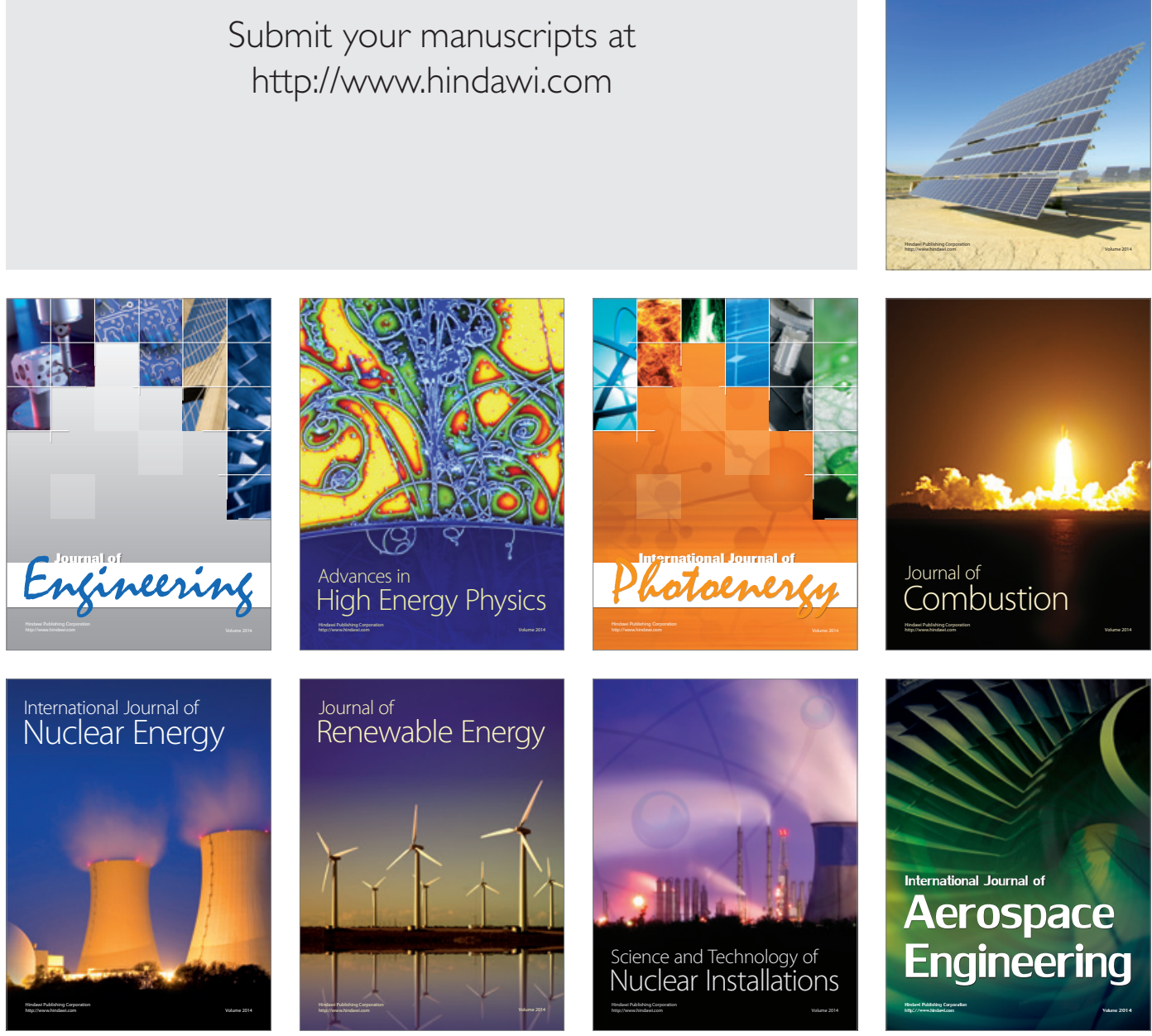